\title{
A STUDY ON CAREER SATISFACTION DIMENSIONS OF IT-ENABLED SERVICE SECTORS (ITES) EMPLOYEES ACROSS YEARS OF EXPERIENCE
}

\author{
Mollimma Mathew*
}

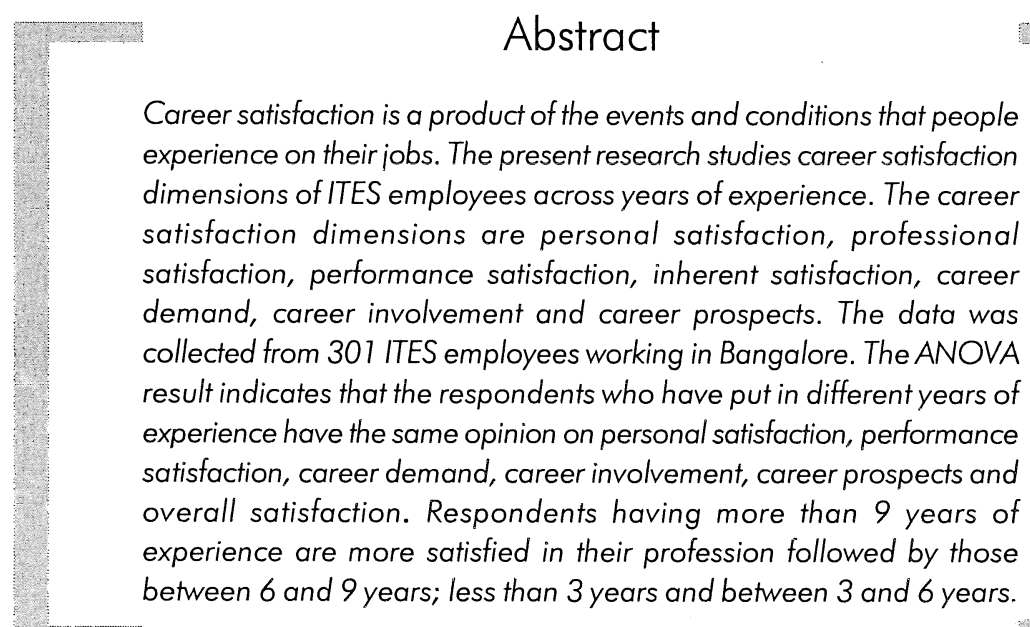

Career satisfaction is a product of the events and conditions that people experience on their jobs. The present research studies career satisfaction dimensions of ITES employees across years of experience. The career satisfaction dimensions are personal satisfaction, professional satisfaction, performance satisfaction, inherent satisfaction, career demand, career involvement and career prospects. The data was collected from 301 ITES employees working in Bangalore. The ANOVA result indicates that the respondents who have put in different years of experience have the same opinion on personal satisfaction, performance satisfaction, career demand, career involvement, career prospects and overall satisfaction. Respondents having more than 9 years of between 6 and 9 years, less than 3 years and between 3 and 6 years. .

* Dept. of Psychology, Kristu Jayanti College, K. Narayanapura, Kothannur PO, Bangalore-77. 


\section{Introduction}

Any service that is carried out based on the application of Information Technology could be termed as an IT-Enabled service. IT-Enabled service thus covers the entire range of services, which exploit information technology, for empowering an organization with improved efficiency. Career growth in the industry is robust and there is a long-term opportunity. The great growth momentum that the industry is witnessing is creating both vertical and lateral career opportunities. The advantage for India being the largest base for ITES is that the rapid growth in telecom services, a pool of highly competent and inexpensive English speaking graduates, higher computer literacy rate, and skilled quality conscious professionals. Increasing the outsourcing process has enabled the government to endorse changes in the process of managing employment as it can no longer invest in a big way in education, and the cost of education will drive the younger ones to join the work force.

Career satisfaction is a product of the events and conditions that people experience on their jobs. When a person's work is interesting, pay is fair, promotional opportunities are good, highly competent profession, Psychological conditions are conducive supervisor is supportive, and coworkers are friendly, then a situational approach leads one to predict that he / she is satisfied with his/her career.

\section{Objective of the Study}

To study the significant difference existing on the study variables across different years of experience

\section{Related Literature}

The present study is to capture career satisfaction dimensions in IT Enabled services, few literatures which throw some light on the understanding of concepts, definitions, methodology and analytical view points are reviewed and discussed The related literature has been classified under two headings.

- $\quad$ The studies on ITES

- The studies on career satisfaction

According to a study conducted by NASSCOM, "In recent years, the ITES sector has posted the highest growth among all the segments in India's growing software and services marketplace, reaching a revenue of Rs. 7100 crore in 2001 - 2002. 
This growth is in overall global industry trends, and is likely to continue over the next few years."

Kumar. (2004), HR consultant New Delhi studied the effect of career anchors on the relationship between job characteristics and organizational citizenship behaviour. The result lent a strong support to hypothesis that there is a positive relationship between job characteristics and job anchors and managerial competence. Career anchors reflect what motivates people on their jobs. The study had hypothesized that if a person's job characteristics match his/her career anchors; the person would experience career satisfaction and would then display organizational citizenship behavior as a result of this satisfaction.

The review indicates that there is enough opportunities for ITES job opportunities. The Profession and the Industry include information about industry demographics, types and sizes of centers, as well as the numbers of folks that work in the profession. In the field of ITES many studies and surveys are conducted on job opportunities retention, attrition, etc. but the researcher could not identify any studies conducted in the field of career satisfaction in ITES sectors, especially in Bangalore. More significantly, Bangalore city has the distinction of being an active centre for ITES companies and a commercial centre for more than 100 multinational companies. The Researcher felt the need to investigate the predictors of their career satisfaction and professional development options available to them in this industry. So there is an emerging need to make them aware of their career choices, career prospects, career demand, career involvement, career satisfaction and overall satisfaction in this field. Hence this study on career satisfaction dimensions can help the ITES employees and people who are joining the industry.

\section{Methodology}

For the purpose of studying the objectives and testing the hypotheses, a questionnaire was used as an instrument to collect the data. The questionnaire has two parts: the first part measures the background information, the second part is the predictors of career satisfaction. Career satisfaction is captured as a construct that constitutes sub-scales on career satisfaction predictors such as personal satisfaction, professional satisfaction, performance satisfaction, inherent satisfaction, career demand, career involvement and career prospects. The items capturing each factor were adopted from standardized questionnaires developed or used by earlier researchers. However, they were subjected to validity and reliability tests. Hence, the items that constituted with adequate coverage of the factors under study were decided and agreed upon by the researcher. 
These items were made on a 5-point scale. Personal satisfaction, professional satisfaction, performance satisfaction, inherent satisfaction, career demand, and career involvement were anchored by $5=$ highly satisfied; $4=$ satisfied; $3=$ neither satisfied nor dissatisfied;

2 = dissatisfied and; $1=$ strongly dissatisfied and the mean of the items under each factor was used as a composite measure of the respective factors. Career prospects was anchored on $1=$ strongly disagree; 2 = disagree; $3=$ neither agree nor disagree; $4=$ agree and $5=$ strongly agree and the mean of the items under each factor was used as a composite measure of the respective. After finalizing the number of items in the research instrument using face and content validity tests, a pilot study was undertaken for the following reasons:

a. To assess the reliability of the research instrument constructed.

b. To ascertain the time taken to complete the questionnaire by the respondents.

The data collected from the pilot study was subjected to reliability test using Cronbach Alpha. The reliability coefficients for the variables chosen for this study are more than 0.60 , which is an acceptable value (Malhotra, 2004). So, the items constituting each variable under study have reasonable internal consistency.

The geographical area of Bangalore city was chosen as the Universe. Bangalore city has the distinction of being an active centre for ITES companies. A list of ITES companies, situated in Bangalore was prepared. From this list, only those organisations which had existed for at least 5 years were chosen. After identifying the organisations, snowball sampling technique was used to collect the data

The questionnaire was administered to all the 500 employees identified. A thorough follow-up was done in person and over telephone to expedite the process of filling up the questionnaire. Yet few questionnaires were not returned and few were unusable and incomplete, yielding a response rate of $60.2 \%$ (301 usable questionnaires.

\section{Analysis and Discussion}

Objective 1. To measure the selected dimensions related to career satisfaction

The selected dimensions related to career satisfaction are personal satisfaction, professional satisfaction, performance satisfaction, inherent satisfaction, career demand, career involvement, career prospects and overall satisfaction. Each 
dimension has been measured using few other items. A composite mean of the items that constitute each dimension has been obtained. Subsequently, objective 1 has been studied by taking the mean of the composite mean of the items that constitute each dimension. The results are given below:

Table IV.1 showing the mean and standard deviation of the study variables

\begin{tabular}{|l|c|c|}
\hline Variables & Mean & Std. Deviation (SD) \\
\hline Personal satisfaction & 3.50 & .31 \\
Professional satisfaction & 3.62 & .38 \\
Performance satisfaction & 3.69 & .39 \\
Inherent satisfaction & 3.50 & .34 \\
Career demand & 3.66 & .43 \\
Career involvement & 3.46 & .47 \\
Career prospects & 4.28 & .25 \\
Overall satisfaction & 3.66 & .39 \\
\hline
\end{tabular}

The table IV. 1 shows the mean and standard deviation of the study variables. It is seen that the mean ranges from a lower value of 3.46 for career involvement to a high of 4.28 for career prospects. Similarly, the SD ranges from a low of 25 for career prospects to a high of 0.47 for career involvement. The standard deviation appears to be relatively lower which indicates that the opinion of the respondents on the study variables is slightly consistent. This is more explicit on career prospects where the mean value is high with a lower SD.

To study the significant difference existing on the study variables across different years of experience.

To compare the opinion of the respondents on the study variables across different years of experience, One Way ANOVA was used. Total years of experience was entered in the ANOVA model as the fixed factor and the study variables such as personal satisfaction, professional satisfaction, performance satisfaction, inherent satisfaction, career demand, career involvement, career prospects and overall satisfaction were entered as the dependent variables. 
Table IV.2. showing ANOVA results across total years of experience

\begin{tabular}{|l|c|c|}
\hline Variables & F Value & Significance Level \\
\hline Personal satisfaction & .193 & .901 \\
Professional satisfaction & $3 . .556^{*}$ & .015 \\
Performance satisfaction & 2.262 & .081 \\
Inherent satisfaction & $3.467^{*}$ & .017 \\
Career demand & 1.823 & .143 \\
Career involvement & 1.50 & .215 \\
Career prospects & .506 & .678 \\
Overall satisfaction & 2.09 & .100 \\
\hline
\end{tabular}

* Significant at 0.05 level,

Source: Primary Data

The above table shows the ANOVA results. It is seen that the respondents across years of experience significantly differ on professional satisfaction and inherent satisfaction. For other variables such as personal satisfaction, performance satisfaction, career demand, career involvement, career prospects and overall satisfaction, the respondents do not significantly differ across years of experience. This means that respondents who have put in different years of experience have the same opinion on personal satisfaction, performance satisfaction, career demand, career involvement, career prospects and overall satisfaction.

On examination of table based on significance in ANOVA, it is seen that respondents with more than 9 years experience have higher professional satisfaction followed by those between 6 and 9 years; less than 3 years and those between 3 and 6 years of experience. For inherent satisfaction, respondents belonging to less than 3 years have high inherent satisfaction; followed by those who have between 6 and 9 years; more than 9 years and between 3 and 6 years.

\section{Conclusion and Implications}

Respondents having more than 9 years of experience are more satisfied in their profession followed by those between 6 and 9 years; less than 3 years and between 3 and 6 years. This is positive note for organizations as employees having more number of years of experience are satisfied in their profession. On the contrary, higher experience respondents have less inherent satisfaction. Hence, organizations should evolve policies to enhance the professional satisfaction of lesser experienced groups and inherent satisfaction of higher experienced groups. Increase in 


\begin{tabular}{|c|c|c|c|c|c|c|c|c|c|c|}
\hline 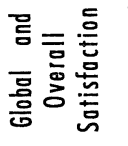 & $\begin{array}{l}\frac{\bar{J}}{\pi} \\
\text { m }\end{array}$ & 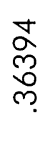 & $\begin{array}{l}0 \\
\text { O̊ } \\
0 \\
\text { ம் }\end{array}$ & $\begin{array}{l}\text { 움 } \\
\text { ğ } \\
\text { ơ }\end{array}$ & 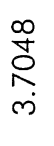 & $\frac{N}{n}$ & 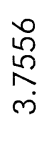 & $\begin{array}{l}\text { Nે } \\
\text { ஸे } \\
\text { లె }\end{array}$ & \begin{tabular}{l}
$\infty$ \\
\multirow{J}{0}{} \\
$D$ \\
$\dot{0}$
\end{tabular} & $\begin{array}{l}\infty \\
\text { m } \\
\infty \\
\infty \\
\text { లె }\end{array}$ \\
\hline 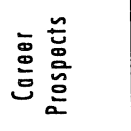 & 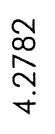 & 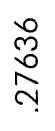 & $\begin{array}{l}a \\
\stackrel{a}{+} \\
\dot{v}\end{array}$ & $\begin{array}{l}\stackrel{0}{+} \\
\text { ণ্ } \\
\text { †̣ }\end{array}$ & 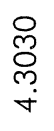 & $\begin{array}{l}\stackrel{0}{\omega} \\
\stackrel{\text { }}{\text { స̦ }}\end{array}$ & \begin{tabular}{l} 
ָ̃ \\
\multirow{\forall}{*}{}
\end{tabular} & 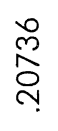 & $\begin{array}{l}\infty \\
+ \\
\stackrel{+}{N} \\
\underset{\forall}{+}\end{array}$ & $\begin{array}{l}\hat{⿵} \\
\text { Oे } \\
\text { ஸे }\end{array}$ \\
\hline 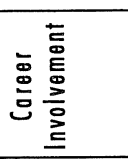 & 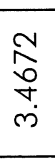 & 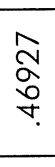 & 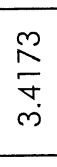 & $\begin{array}{l}\text { 今̀ } \\
\text { ホ̃ } \\
\text { f. }\end{array}$ & $\begin{array}{l}m \\
\ddot{m} \\
\infty \\
\tilde{m} \\
m\end{array}$ & 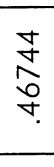 & \begin{tabular}{l}
$\infty$ \\
\multirow{N}{N}{} \\
$\sim$ \\
$m$
\end{tabular} & $\begin{array}{l}a \\
\frac{a}{a} \\
\bar{m}\end{array}$ & $\begin{array}{l}\mathscr{1} \\
\text { Do } \\
\dot{0} \\
\dot{m}\end{array}$ & $\begin{array}{l}0 \\
\circ \\
\infty \\
0 \\
0 \\
+\end{array}$ \\
\hline 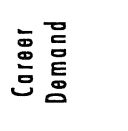 & $\begin{array}{l}\text { o } \\
\text { مे } \\
\text { m. }\end{array}$ & $\begin{array}{l}m \\
\infty \\
\infty \\
m\end{array}$ & $\begin{array}{l}\text { N } \\
\text { No } \\
\text { ウं }\end{array}$ & 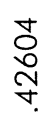 & $\begin{array}{l}\frac{a}{N} \\
\frac{n}{n}\end{array}$ & 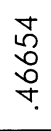 & $\begin{array}{l}\text { L } \\
\text { nn } \\
\text { nं } \\
\text { nं }\end{array}$ & 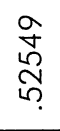 & 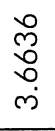 & $\frac{0}{\frac{0}{m}}$ \\
\hline 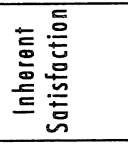 & $\begin{array}{l}\infty \\
2 \\
\hat{N} \\
n\end{array}$ & $\begin{array}{l}\infty \\
\frac{0}{0} \\
\text { p. }\end{array}$ & 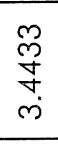 & స్ & $\begin{array}{l}m \\
m \\
m \\
m \\
m\end{array}$ & $\frac{O}{\bar{N}}$ & 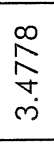 & $\begin{array}{l}n \\
\infty \\
\stackrel{0}{0} \\
\text { p. }\end{array}$ & 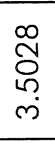 & $\begin{array}{l}\bar{E} \\
\stackrel{n}{m}\end{array}$ \\
\hline 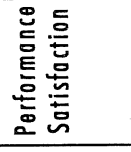 & $\begin{array}{l}\text { Nิ } \\
\text { ஸे }\end{array}$ & $\begin{array}{l}\infty \\
\check{m} \\
\frac{\sigma}{\forall}\end{array}$ & $\begin{array}{l}\bar{a} \\
\text { ñ } \\
\dot{m}\end{array}$ & $\begin{array}{l}\text { N } \\
\text { m } \\
\text { m. }\end{array}$ & $\begin{array}{l}\text { े } \\
\text { రి } \\
\infty \\
\text { mे }\end{array}$ & 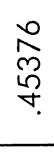 & $\begin{array}{l}0 \\
\infty \\
\infty \\
0 \\
\dot{m}\end{array}$ & $\begin{array}{l}\text { Tे } \\
8 \\
8 \\
\end{array}$ & $\begin{array}{l}a \\
a \\
0 \\
\dot{m}\end{array}$ & $\begin{array}{l}m \\
\infty \\
\infty \\
\infty \\
\infty \\
m \\
\Gamma\end{array}$ \\
\hline 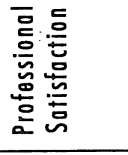 & $\begin{array}{l}\text { Dे } \\
\text { ָै } \\
\text { ம் }\end{array}$ & $\begin{array}{l}\text { mి } \\
\text { mె }\end{array}$ & $\begin{array}{l}5 \\
0 \\
n \\
n\end{array}$ & 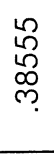 & $\begin{array}{l}8 \\
\stackrel{\circ}{n} \\
\text { m }\end{array}$ & 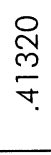 & $\begin{array}{l}\stackrel{a}{\tilde{n}} \\
\stackrel{n}{m} \\
\dot{m}\end{array}$ & 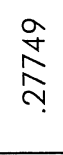 & 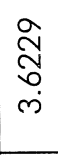 & $\begin{array}{l}\stackrel{N}{\bar{n}} \\
\stackrel{\infty}{m}\end{array}$ \\
\hline 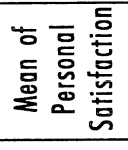 & 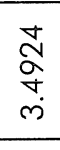 & $\begin{array}{c}\text { O্े } \\
\text { } \\
\text { } \\
\text {. }\end{array}$ & $\frac{\stackrel{m}{N}}{n}$ & 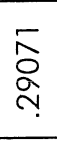 & \begin{tabular}{l} 
No \\
\multirow{\forall}{*}{} \\
లे
\end{tabular} & 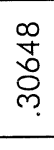 & $\begin{array}{l}\overline{0} \\
\infty \\
+ \\
\dot{m}\end{array}$ & 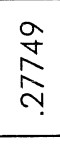 & 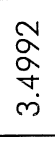 & $\begin{array}{l}0 \\
5 \\
0 \\
\text { n. }\end{array}$ \\
\hline & $\begin{array}{l}\frac{5}{0} \\
\sum^{\mathbb{O}}\end{array}$ & 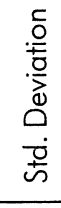 & $\begin{array}{l}\text { c } \\
\mathbb{Q} \\
\sum\end{array}$ & $\begin{array}{l}c \\
. \frac{0}{ \pm} \\
. \frac{0}{\partial} \\
\frac{0}{0} \\
0.0 \\
\dot{0}\end{array}$ & $\begin{array}{l}\text { D } \\
\frac{\Phi}{2}\end{array}$ & 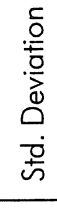 & $\begin{array}{l}0 \\
\frac{0}{d} \\
\sum\end{array}$ & 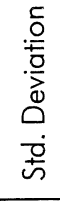 & 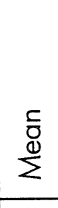 & 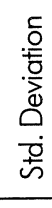 \\
\hline 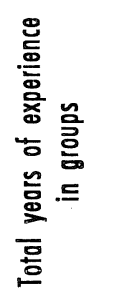 & 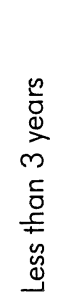 & & 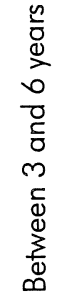 & & 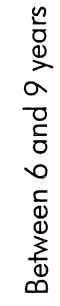 & & 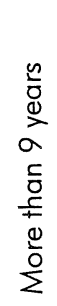 & & 홍 & \\
\hline
\end{tabular}


availability of personal time to take care of the personal needs may be one solution to overcome this effect.

Organizational valid practice should uphold equitable initiatives. The companies could also actively engage and support the employees for career alternatives so that their marketability within the organization increases. Broader training and skill-development opportunities also enhance intention to stay in the organization. Such initiatives help growth with a sense of success or satisfaction. Organizations could benefit and realize productivity and quality gains by fostering effective internal networking with the employees.

\section{References}

Allen, N. J. and Meyer, J. P. (1993). "Organizational Commitment: Evidence of Career Stage Effects," Journal of Business Research, Vol. 29, pp. 49-61.

Anupama Riana. (2008). Journal of Business Research. "Management of call center-employee attrition and retention."

Arulmani, G. (1999). Enhancing the career preparation self efficacy of high school students: Institute for careers Education, Warwick, United Kingdom.

Banks. M (1992). Careers and identities. Milton Keynes, England: Open University press.

Bhargava, M, Sharma, A. (1995). "Scholastic Attainment and career maturity". Indian journal of Psychometric and Education, 26(1).

Blustein, D.L. (1988) Canonical analysis of career choice crystallization and vocational maturity. Journal of Counseling Psychology. 35 (3).

Brown, Mark G. (1996). Keeping Score: Using the Right Metrics to Drive World-Class Performance. New York: Quality Resources.

Cron, W. L., Dubinsky, A. J., and Michaels, R. E. (1988). "The Influence of Career Stages on Components of Salesperson Motivation," Journal of Marketing, Vol. 52, pp. 78-92.

Cynthia D. Fisher, Lyle F, Schoenfeldt, James B. Shaw. (2007). Human Resource Management: $5^{\text {th }}$ edition, pp 61.

Ganesh Chella, (2005.). "Emerging trends Employement 2010" HRM Review, February 2005.

Mount, M. K. (1984). "Managerial Career Stage and Facets of Job Satisfaction," Journal of Vocational Behavior, Vol. 24, pp. 340-354.

Osipow, S. H. (1996). Theories of Career Development, 4th Ed., New York: Prentice Hall.

Sonali Kumar. (2004) Hr consultant New Delhi "The effect of career anchors on the relationship between job characteristics and organizational citizenship behaviour". 